\title{
Islet cell antibodies in normal French schoolchildren
}

\author{
C. Lévy-Marchal ${ }^{1}$, J. Tichet ${ }^{2}$, I. Fajardy ${ }^{3}$, X.F.Gu ${ }^{3}$, F. Dubois $^{2}$ and P.Czernichow ${ }^{1}$ \\ ${ }^{1}$ Service de Diabétologie, Hôpital Robert Debré, Paris; ${ }^{2}$ Institut Régional de Santé, Tours; and \\ ${ }^{3}$ INSERM Unité 125 , Hôpital Robert Debré, Paris, France
}

Summary. Islet-cell antibodies have been reported to be of predictive value for the future development of Type 1 (insulin-dependent) diabetes in first degree relatives of diabetic patients with the risk increasing in these subjects with the islet-cell antibodies titre. However, very little is known about islet-cell antibodies in background populations. Sera $(n=$ 8363) from schoolchildren (6-17 years) in the French background population were screened for the presence of islet-cell antibodies by the indirect immunofluorescence technique. Islet-cell antibodies greater than 4.5 Juvenile Diabetes Foundation units were found in 150 sera (prevalence rate $1.8 \% ; 95 \%$ confidence interval $1.5-2.1 \%$ ). Only 17 sera demonstrated islet-cell antibody titre $\geq 24$ JDF units. No particular feature was found to be significantly different between islet-cell antibody-positive and islet-cell antibodynegative children (age, family history of diabetes, fasting plasma glucose, insulin autoantibodies). A second blood sample was obtained from 80 of 150 islet-cell antibody positive children after a mean interval of 8 months. Only 11 sera became $<4.5$ JDF units with islet-cell antibody titres being stable in the remaining sera, including the high-titre positive sera ( $\geq 24$ JDF units). HLA-DQB typing was performed by restriction mapping techniques in 80 islet-cell antibody-positive, in 93 islet-cell antibody-negative and in 213 Type 1 diabetic children. The distribution of the susceptibility alleles (DQB1-Asp57-negative) was not significantly different between islet-cell antibody-positive and islet-cell antibodynegative children. This survey has identified a low islet-cell antibody prevalence rate in French schoolchildren, among whom the incidence rate of Type 1 diabetes is one of the lowest in Europe. The genetic study indicates that part of this group of children are not prone to developing the disease. The predictive value of islet-cell antibodies in normal children will be estimated during the long-term follow-up of this population.

Key words: Islet-cell antibodies, prevalence rate, HLA-DQ region, Type 1 (insulin-dependent) diabetes mellitus, children.
More than 15 years ago islet-cell autoantibodies (ICA) were identified in sera from patients with recent onset Type 1 (insulin-dependent) diabetes mellitus [1]. The presence of these antibodies is one of the indications that Type 1 diabetes is an autoimmune disease. ICA are also important for the description of the long latent period preceding the diagnosis of the overt disease [2], and several surveys have evaluated the predictive value of ICA which appear to be currently the best marker for the development of the disease in first degree relatives of Type 1 diabetic patients [3]. The overall risk has been estimated to be $8 \%$ per patient-year, but the predictive value increases considerably with ICA titres [4-6].

Although the risk of Type 1 diabetes is increased in first degree relatives, familial cases represent the minority of the patients. Most of the cases are sporadic and much knowledge is to be gained from the markers of the prediabetic phase in this group of patients.
Several studies have reported on prevalence rates of ICA in background populations, examining samples of various sizes (Table 1) [7-12]. Geographic variations have been observed and some authors have speculated on the possible relationship between prevalence of ICA in the background population and the incidence of the disease [13-18]. However, no study has yet focused on other autoimmune markers or on genetic risk markers, especially on HLA typing of ICA-positive subjects.

We have therefore designed a survey aiming at evaluating the prevalence rate in schoolchildren from the French background population. It is noteworthy that the incidence rate of Type 1 diabetes is one of the lowest in Europe [19]. Another aim was to describe the group of ICA-positive children in terms of clinical history, other markers of autoimmunity and HLA typing, comparing ICA-positive subjects to age-matched ICA-negative subjects and to a group of diabetic children. 
Table 1. Prevalence data in children from background populations and incidence of Type 1 (insulin-dependent) diabetes in the same countries

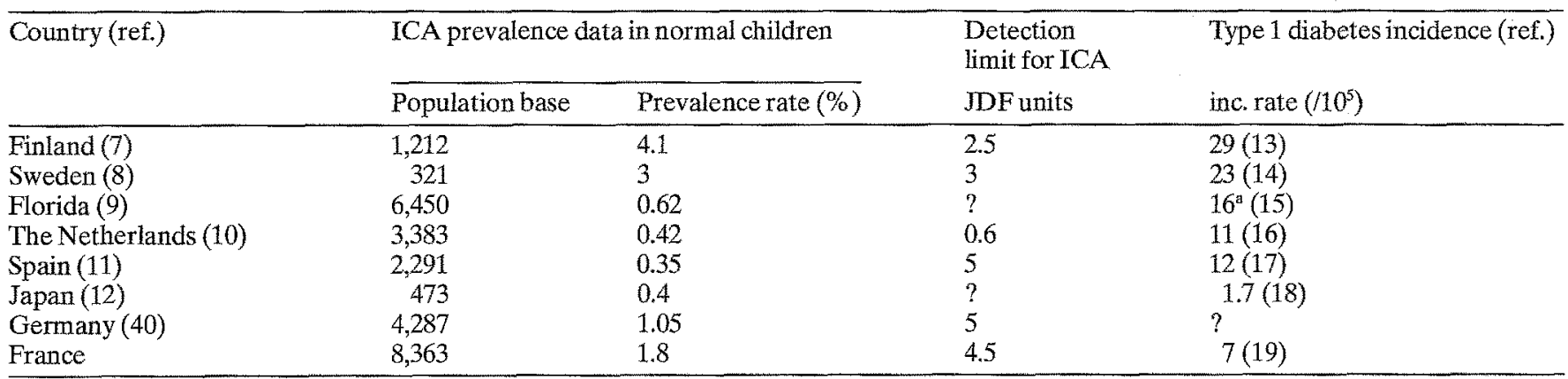

"Incidence rate has not been evaluated in Florida, but in Pennsylvania. ICA, islet-cell antibodies; JDF, Juvenile Diabetes Foundation

\section{Subjects and methods}

\section{Subjects}

Sera from 8,363 children, 4,260 boys and 4,103 girls, aged $6-17$ years, were anonymously screened for the presence of ICA. Sera were collected between October 1989 and June 1990 at the Institut Régional de Santé (IRSA, Tours) which is responsible for organizing and performing free health examinations on adults and their children with parental consent. A standard medical questionaire was filled in for each child, relating to family and personal medical history. Children underwent physical examination. Reactive strips (Labstix, Ames, Puteaux, France) were used to test for glycosuria. Blood was drawn to determine the fasting glucose level among other usual parameters; $1 \mathrm{ml}$ was immediately centrifuged and the serum kept at $-80^{\circ} \mathrm{C}$ until ICA determination.

Results of ICA positivity and information on the research programme were given to the family practitioners responsible for the follow-up of these children. Out of 150 ICA-positive children 80 are participating and a second blood collection was obtained in these children. Sera and cells were used for the subsequent ICA determination and HLA-DQ typing and measurement of glycated haemoglobin.

Approval from the Ethics Committee of the Paris VII University School of Medicine was obtained for the study design.

Type 1 diabetic children $(n=213)$ were randomly recruited from the patients attending the paediatric diabetes clinic at the Robert Debré hospital (Paris) and were used for comparison in the HLADQ study only.

\section{Analytical methods}

ICA were detected by the indirect immunofluorescence method using a single human blood group $\mathrm{O}$ pancreas [20]. Results were determined as the last serum dilution containing ICA positivity; each titre was then converted into JDF units as recommended by the $3^{\text {rd }}$ International Workshop on Standardization of ICA [21]. The end point titre of the standard JDF serum was $1: 64$. The detection limit for an undiluted positive serum was 4.5 IDF units. Coefficients of variation for day to day precision were $15 \%$ and $24 \%$ at 48 and 4.5JDF units respectively. Each positive serum was read by two independent observers; in case of discrepancy a third observer was consulted, and the sample reanalysed in another series. Three hundred negative sera were randomly selected and assayed in a separate run, several months apart, to assess the consistency of negativity.

Insulin autoantibodies (IAA) were determined in the first 2,000 sera, arbitrarily chosen for this part of the study. They were measured by the radioimmunobinding method using human iodinated insulin and serum stripping by acid precipitation and charcoal extraction. The detailed procedure has been previously described [22]. A serum was considered IAA positive if the total and the dis- placeable insulin bindings were simultaneously above $3 \mathrm{SD}$ of the reference means ( $2.9 \%$ and $1.13 \%$ respectively).

Anti-microsomal thyroid auto-antibodies were tested according to the method described by Doniach et al. [23].

Glycated haemoglobin was measured by ion exchange high performance chromatography on an automated chromatograph (Diamat, Biorad, Richmond Calif, USA) with a mean reference value of $5.1 \pm 0.3 \%$ (inter-assay coefficient of variation $=1.2 \%$ for $\mathrm{HbA}_{1 \mathrm{c}}$ at $5 \%)$.

HLA typing was performed by the identification of susceptibility alleles at the DQ region. DNA was extracted from peripheral blood leucocytes. Exon 2 of the HLA-DQB1 genes were amplified using the polymerase chain reaction (PCR). The polymorphism of DQB1 locus was studied by differential restriction mapping as already described [24]. This method allows the identification of 11 alleles. Seven alleles coding for a residue different from an aspartate at position 57 of the $\beta$ chain are defined as susceptibility alleles and four allelles coding for an aspartate residue are defined as protective alleles.

\section{Statistical analysis}

ICA titres and JDF units were $\log _{2}$ transformed before calculation and the results are given for geometric means $\pm S D$. Chi-square analysis was used for comparisons of frequencies. All calculations were performed with the Fastat computer program (Systat Inc., Evanston Ill., USA).

\section{Results}

\section{ICA prevalence rates}

ICA positivity was found in 150 sera, with a prevalence rate of $1.79 \%$ ( $95 \%$ confidence limits: $1.50-2.08 \%$ ). No significant difference was observed in the prevalence rates according to age and sex (Table 2). The prevalence data according to the sera titres are indicated in Table 3 . The majority of the sera were weakly positive (undiluted positive sera: $49 \%$ ). Seventeen sera showed $\geq 24 \mathrm{JDF}$ units. There was no significant variation in ICA titres with age.

\section{Characteristics of the ICA-positive children}

ICA-positive and negative children did not differ in age (means $=11.5 \pm 2.4$ and $11.3 \pm 2.2$ years, respectively). One female was already a known diabetic patient in the ICA-positive group but none in the ICA-negative group. 
Table 2. Distribution of ICA positivity according to age and sex in 8,363 schoolchildren

\begin{tabular}{lclll}
\hline Age (years) & $6-9$ & $10-15$ & $16-17$ & Total \\
\hline $\begin{array}{l}\text { Males } \\
\text { Population }\end{array}$ & 855 & 3,210 & 195 & 4,260 \\
$\begin{array}{l}\text { ICA + } \\
\text { Prevalence rate }\end{array}$ & 24 & 62 & 3 & 89 \\
$\begin{array}{l}\text { (\%) } \\
\text { Females }\end{array}$ & & 1.93 & 1.53 & 2.08 \\
Population & 828 & 3,110 & 165 & $4.64-2.50)$ \\
$\begin{array}{l}\text { ICA + } \\
\text { Prevalence rate }\end{array}$ & 6 & 50 & 5 & 61 \\
(\%) & 0.72 & 1.60 & 3.03 & 1.48 \\
& & & & $(1.10-1.86)$ \\
Total & & & & \\
$\begin{array}{l}\text { Population } \\
\text { ICA + }\end{array}$ & 1,683 & 6,320 & 360 & 8.363 \\
$\begin{array}{l}\text { Prevalence rate } \\
\text { (\%) }\end{array}$ & 30 & 112 & 8 & 150 \\
& 1.78 & 1.77 & 2.22 & 1.79 \\
& & & & $(1.50-2.08)$ \\
& & & &
\end{tabular}

The numbers in brackets represent the $95 \%$ confidence limits of the given prevalence rates. ICA, islet-cell antibodies

Table 3. Prevalence data of ICA positivity according to sera titres

\begin{tabular}{lccl}
\hline $\begin{array}{l}\text { ICA titre } \\
\text { (JDF units) }\end{array}$ & Number of sera & $\%$ & $\begin{array}{l}\text { Prevalence rate } \\
(\%)\end{array}$ \\
\hline 4.5 & 73 & 49 & 0.87 \\
$8-14$ & 60 & 40 & 0.72 \\
$\geq 24$ & 17 & 11 & 0.20 \\
Overall & 150 & 100 & $1.79(1.5-2.08)$ \\
\hline
\end{tabular}

ICA, islet-cell antibodies; JDF, Juvenile Diabetes Foundation

No significant difference was observed in the reported data on family history of diabetes (siblings, parents or grand-parents having Type 1 or Type 2 diabetes) between either group of children; this information was available in 150 of 150 ICA-positive and in 7462 of 8213 ICA-negative children. None of the ICA-positive children was a first degree relative of a Type 1 diabetic patient. Fasting plasma glucose distributions were similar in the two groups (Fig. 1). Among the 150 ICA-positive subjects, nine demonstrated plasma glucose levels outside the reference interval for age: five were lower, and four were greater including the diabetic child. In these nine children ICA titres were $\leq 8$ JDF units, except in the diabetic child (24 JDF units) and in the child with the lowest blood glucose level (2.88 mmol/1; 24 JDF units).

\section{Follow-up of the ICA positive children}

A second blood sample was obtained in 80 children after a mean interval of 8.3 months (range: $5-15$ months). These 80 children did not differ from the remaining 70 ICApositive children in terms of age, family history of diabetes and distribution of ICA titres (Fig. 2).

Eleven sera became negative (which were previously undiluted positive) and the rest of the sera remained stable within an interval of two doubling dilutions; two sera gained more than two titre dilutions between the first and the second sample. One serum was both ICA- and IAA-positive on the first sample but lost IAA-positivity on the second one. None of the 80 sera were positive for anti-microsomal thyroid autoantibodies. All $\mathrm{HbA}_{1 \mathrm{c}}$ values were normal (range: $4.0-5.3 \%$ ).

One 7 -year-old boy has become diabetic 10 months after the first screening. ICA were 42 JDF units on the first sample, and an identical titre was found 7 months later. At the second blood sampling ( 3 months before the diagnosis of diabetes) $\mathrm{HbA}_{1 c}$ was normal. IAA were found negative at the two time points. This boy carried two susceptibility alleles at the HLA-DQB region.

None of the 70 children in whom a second blood sample could not be collected have become diabetic; this information was gathered using a questionaire mailed to the family practitioners of these children with a mean follow-up of 10 months.

\section{Insulin autoantibodies (IAA)}

All the ICA-positive sera and the first 2,000 ICA-negative sera were screened for the presence of IAA. The prevalence rate was $1.15 \%$ (95\% confidence limits: 0.6$1.6 \%$ ) among 2,000 sera. The mean total insulin binding was $7.43 \%$ (range: $3.10-32.0 \%$ ) in the IAA-positive sera $(n=22)$. Two ICA-positive sera ( 8,8 and 24 JDF units.) were simultaneously IAA-positive (3.27 and 3.75 of total insulin binding). The serum from the insulin-treated diabetic child contained ICA (24 JDF units) and insulin antibodies (insulin binding: $30.4 \%$ ).

A second sample was obtained from 16 of 22 IAA-positive children, 10 months apart. Two children were both ICA- and IAA-positive at the first determination and were stable for ICA-positivity on the second determination, but one serum only remained IAA-positive. The other 14 sera became IAA-negative and remained ICAnegative.

\section{HLA-DQB typing}

HLA-DQB typing was performed in 80 ICA-positive, in 93 matched ICA-negative and in 213 Type 1 diabetic children. Table 4 indicates the distribution of the allelic

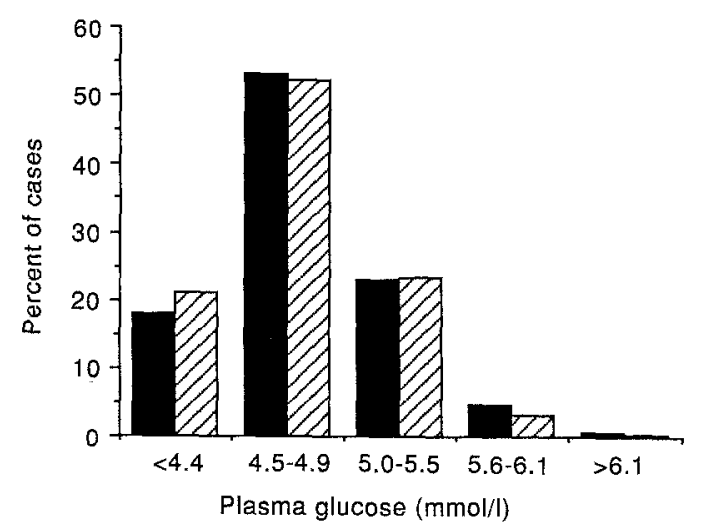

Fig.1. Distribution of fasting plasma glucose in $150 \mathrm{ICA}$ positive ( $)$ and 8,213 ICA negative ( $\square$ ) children 


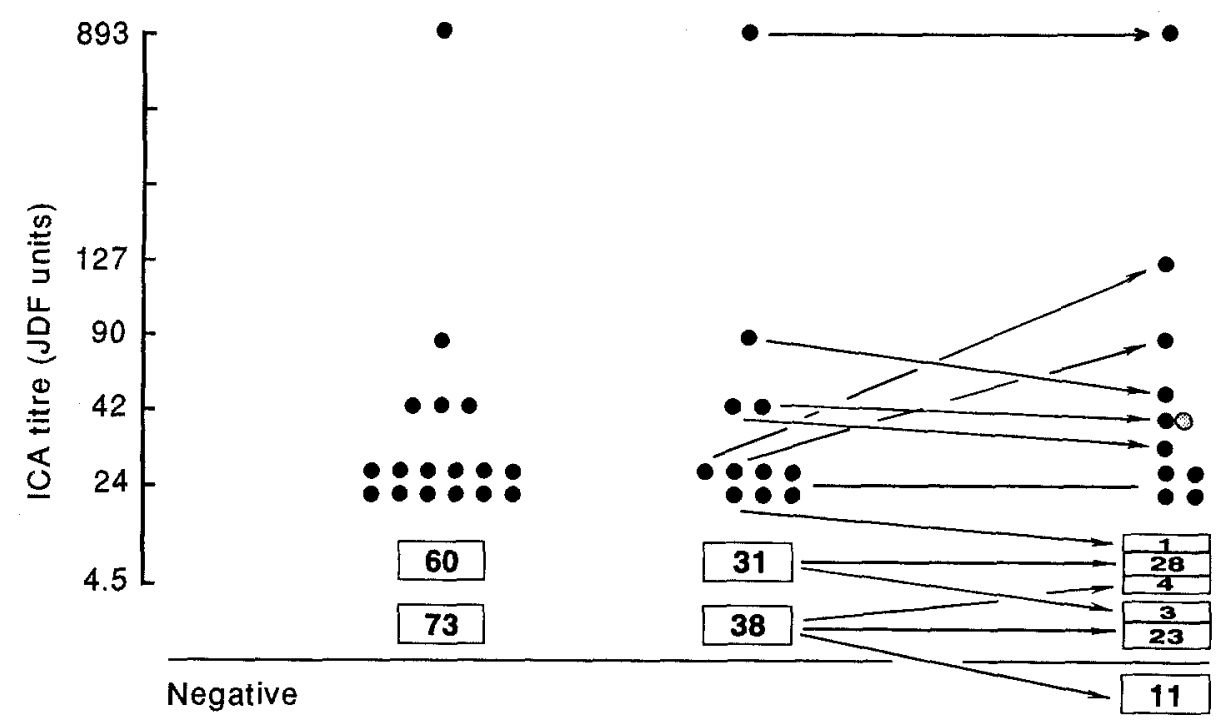

First determination

$\begin{array}{cc}\text { All samples } & \text { Subgroup available for } \\ (n=150) & \text { a } 2^{\text {nd }} \text { determination }(n=80)\end{array}$

combinations coding for a non-aspartate residue at position 57 of the $\beta$ chain in the three groups. Distributions were not significantly different between the ICA-positive and negative groups, but were highly significantly different between diabetic and ICA-positive children $(p<0.01)$.

\section{Discussion}

Identification of ICA in serum from first degree relatives of Type 1 diabetic patients is an important marker of the prediabetic phase preceding the overt diagnosis of the disease as attested by almost all the family studies [3,5,6,25]. However, it must be emphasized that familial cases are a minority and that the large majority of new cases are sporadic. In a recent survey in France, it has been found that only $7 \%$ of the incident cases developed in already affected famlies [26]. It seems reasonable therefore to create screening programmes for people from background, low-risk populations since this is where most cases will occur.

Table 4. Distribution of the allelic combinations at the DQB1-HLA region in ICA positive, ICA negative and in Type 1 (insulin-dependent) diabetic children

\begin{tabular}{lllllrr}
\hline $\begin{array}{l}\text { Allelic } \\
\text { combinations }\end{array}$ & $\begin{array}{l}\text { ICA-positive } \\
(n=80)\end{array}$ & \multicolumn{2}{l}{$\begin{array}{l}\text { ICA-negative } \\
(n=93)\end{array}$} & \multicolumn{2}{l}{$\begin{array}{l}\text { Diabetic children } \\
(n=213)\end{array}$} \\
\hline DQB1 & $n$ & $\%$ & $n$ & $\%$ & $n$ & $\%$ \\
position 57 & & & & & & \\
\hline NA/NA & 27 & 34 & 18 & 30 & 183 & 86 \\
NA/Asp & 35 & 44 & 41 & 44 & 28 & 13 \\
Asp/Asp & 18 & 22 & 24 & 26 & 2 & 1 \\
\hline
\end{tabular}

NA, amino-acid different from aspartic acid at position 57; ICA, islet-cell antibodies
Second
determination
$(n=80)$
Fig. 2. Distribution and follow-up of islet-cell antibody (ICA) positive sera according to titres expressed in Juvenile Diabetes Foundation (JDF) units. Numbers of sera between given JDF units limits are indicated in framed squares for each series. Sera with titres $\geq 24 \mathrm{JDF}$ units are represented individually by solid black dots. The shaded grey dot represents the serum from the child who became diabetic. The second serum sample was obtained after a mean interval of 8.3 months after the first collection
ICA screening in children from background population is a difficult and laborious task. This goal has been achieved in few countries and large variations in the ICA prevalence rates have been reported between countries ranging from $4.1 \%$ in Finland to $0.35 \%$ in Spain. Interestingly enough, similar geographical disparities have been observed in incidence rates of the disease (under 15 years of age) in these very countries.

Before any speculation on the meaning of these data, several pittfalls in screening methodology and ICA assay are to be examined: the size of the population sample and the sensitivity and precision of the ICA assay. It has been shown that the ICA detection limit is highly variable between laboratories [27] mainly due to the quality or the nature of the pancreas used as substrate [28]. As the low titres sera ( $<15-20$ JDF units) represent the largest component of ICA positive sera in all of these studies, decreasing the detection limit would increase the overall number of positive sera and therefore increase the prevalence rates. If we look at the numbers of sera containing high titres of ICA ( $\geq 20 \mathrm{JDF}$ units) the prevalence rates fall to very low values in each country: none in Spain, $0.15 \%$ in the Netherlands, $0.26 \%$ in Florida, $1.8 \%$ in Sweden and $2.9 \%$ in Finland. In our population $11 \%$ of ICA-positive children demonstrated a high titre ( $\geq 24$ JDF units). ICAtitres were found remarkably stable over time. More strikingly, the 11 patients with titres $\geq 24$ JDF units remained elevated. ICA-positivity scarcely disappeared, except in the very low titre ICA-positive sera, as already reported in siblings [29].

ICA are identified in the majority of Type 1 diabetic children at the time of diagnosis [1]. However, despite sensitive assays about $20 \%$ of the children are persistently found to be ICA-negative at the onset of the disease [30]. ICA have been recognized in 3-13\% of the siblings of Type 1 diabetic patients, according to the assay and the 
number of subjects. Interestingly, all these studies identified the large majority of ICA-positive relatives at the time of the first screening, and very few "converters" have been observed during the follow-up period. Two factors interfere strongly with the relative risk attributed to the presence of ICA: titre and age. The risk of developing Type 1 diabetes within 8 years becomes much higher if ICA are $\geq 20-40$ JDF units $[4,6]$, and if age at initial testing is $\leq 10$ years [5]. In children from background population, three studies clearly indicate that ICA-positivity may figure as a risk marker for the disease. In the studies from Florida and Finland, it was indicated that persisting high titres of ICA confined a far higher risk. In our survey, one child became diabetic within 1 year and exhibited persisting ICA at 42 JDF units. Conversely, we found a poor informative value ascribed to the presence of IAA-positivity, as already reported in some family studies $[6,31]$.

In each country the number of children found to be ICA-positive was much greater than expected from calculations on incidence rates of Type 1 diabetes. If the number of ICA-positive children is large not all these children will progress to developing the disease. ICA-positivity could be a sign of non-specific immune activation by exogeneous factors such as viruses [32]. The remarkable stability of ICA titres observed in this study and the lack of antithyroid antibodies, as already reported [33], do not argue in favour of this hypothesis.

It has been shown that Type 1 diabetes develops among HLA identical or haplo-identical siblings to the affected proband and that the risk is increased if the shared phenotypes are DR3 or DR4 [34]. Results in the literature are rather conflicting about ICA-positivity and HLA status. Vexiau et al. reported that there was no association in siblings between ICA-positivity and HLA identity [35]. In the studies from Oxford and Lyon, ICA-positivity was not associated with a given haplotype. DR antigens are in linkage desequilibrium with restricted phenotypes at the DQ region [36]. Todd et al. have shown that DQB1 alleles encoding an amino-acid different than an aspartic acid at position 57 of the $\beta$ chain determined a high relative risk for Type 1 diabetes [37]. Using these techniques, Lipton et al. have recently shown that the distribution of the DQB genetic markers did not differ among ICA-negative and positive siblings of diabetic children. On the other hand, the 18 ICA-positive siblings who developed Type 1 diabetes carried the susceptibility alleles at the DQB region [38]. Genetic studies in ICA-positive schoolchildren are rare. They have been carried out only in Florida in the 16 high titre ICA-positive children: $31.3 \%$ (vs $2.5 \%$ in control subjects) were DR3/4 heterozygotes and $6.3 \%$ lacked these antigens. In Germany, high levels of ICA were found to be associated with the non-aspartate-57 DQB1 alleles in children from the background population [39]. We found no significant difference in the distribution of the susceptibility alleles between ICA-positive and -negative children. If we consider the high titre ICA-positive children, three of them $(33 \%)$ carried two major susceptibility alleles (*0201 and/or *0302- data not shown).

This study has identified a large group of children exhibiting at least one risk marker for Type 1 diabetes. Two pieces of evidence suggest that this group is heteroge- neous. Firstly, the number of individuals is greater than expected from calculations based upon incidence data of the overt disease in France. Secondly, 22\% of the children carry an HLA genotype rarely found in diabetic children. In twins, it has been recently reported that ICA-positivity and glucose intolerance under oral glucose load could be seen in the second twin at the time of diagnosis of the twin proband [40]. These abnormalities were transient, consistent with the hypothesis that ICA could be the witness of insulitis, and that some individuals are able to recover from these attacks, not developing diabetes. A longer follow-up of this population will be necessary to better define the risk of developing Type 1 diabetes previously ascribed to ICA in high-risk groups.

Acknowledgements. We gratefully acknowledge Mr. M. Hairy for his skilful technical assistance, and Dr. M.O.Bitker (Hôpital Salpêtrière, Paris) for providing the human pancreas. This work was supported by a grant from L'Aide aux Jeunes Diabétiques (Paris). The authors acknowledge the valuable contribution of the family practitioners involved in this project.

\section{References}

1. Bottazzo GF, Florin-Christiansen A, Doniach D (1974) Islet-cell antibodies in diabetes mellitus with autoimmune polyendocrine deficiencies. Lancet II: 1279-1283

2. Srikanta S, Ganda OP, Eisenbarth GS, Soeldner JS (1983) Islet cell antibodies and $\beta$ cell function in monozygotic triplets and twins initially discordant for Type 1 diabetes mellitus. N Engl $\mathbf{J}$ Med 308: 322-325

3. Tarn AC, Thomas JM, Dean BM et al. (1988) Predicting insulindependent diabetes. Lancet I: $8545-8550$

4. Bonifacio E, Bingley PJ, Shattock M et al. (1990) Quantification of islet-cell antibodies and prediction of insulin-dependent diabetes. Lancet 335: 147-149

5. Riley WJ, MacLaren N, Krischer J et al. (1990) A prospective study of the development of diabetes in relatives of patients with insulin-dependent diabetes. N Engl J Med 323: 1167-1172

6. Thivolet C, Beaufrère B, Gebuhrer L, Chatelain P, Orgiazzi J (1991) Autoantibodies and genetic factors associated with the development of Type 1 (insulin-dependent) diabetes in first degree relatives of diabetic patients. Diabetologia 34: 186-191

7. Karjalainen JK (1990) Islet-cell antibodies as predictive markers for IDDM in children with high background incidence of disease. Diabetes 39: 1144-1150

8. Landin-Olsson M, Karlsson A, Dahlquist G, Blom L, Lernmark $\AA$, Sundkvist G (1989) Islet cell and other organ-specific autoantibodies in all children developing Type 1 diabetes mellitus in Sweden during one year and in matched control children. Diabetologia 32: 387-395

9. Mac Laren N, Horne G, Spillar R, Barbour H, Harrson D, Duncan J (1990) The feasibility of using ICA to predict IDDM in US school children. Diabetes 39 [Suppl 1]: 122A (Abstract)

10. Bruining GJ, Molenaar JL, Grobbee DE et al. (1989) Ten-year follow-up study of islet-cell antibodies and childhood diabetes. Lancet I: $1100-1103$

11. Bergua M, Sole J, Marion G et al. (1987) Prevalence of islet-cell antibodies, insulin antibodies and hyperglycaemia in 2291 school children. Diabetologia 30: 724-726

12. Notsu K, Oka N, Note S, Nabeya N, Kuno S, Sakurami T (1985) Islet cell antibodies in the Japanese population and in subjects with Type 1 (insulin-dependent) diabetes. Diabetologia 28: $660-662$

13. Reunanen A, Ảkerblom HA, Kaar ML (1982) Prevalence and ten-year incidence of insulin-dependent diabetes mellitus in 
children and adolescents in Finland. Acta Paediatr Scand 71: 893-899

14. Dahlquist G, Gustavsson KH, Holmgren G et al. (1982) The incidence of diabetes mellitus in Swedish children 0-14 years of age. A prospective study 1971-1980. Acta Paediatr Scand 71: $7-14$

15. Laporte RE, Fishbein HA, Drash AL et al. (1981) The Pittsburgh insulin-dependent diabetes mellitus registry. The incidence of insulin-dependent diabetes mellitus in Allegheny county, Pennsylvania (1965-1976). Diabetes 30: 279-284

16. Vaandrager GJ, Bruining J, Veenhof FJ, Drayer NM (1984) Incidence of childhood diabetes in the Netherlands: a decrease from north to south over north-western Europe. Diabetologia 27: 203-206

17. Goday A, Castell C, Tresseras R et al. (1991) Incidence of Type 1. (insulin-dependent) diabetes mellitus in Catalonia, Spain. Diabetologia 35: 267

18. Tajima N, Laporte RE, Kitawaya T, Fujita H, Drash AL (1985) A comparison of the epidemiology of youth onset insulin-dependent diabetes mellitus between Japan and the United States (Allegheny county, Pennsylvania). Diabetes Care 8 [Suppl.1]:17-23

19. Lévy-Marchal C, Papoz L, de Beaufort C et al. (1990) Incidence of juvenile Type 1 (insulin-dependent) diabetes in France. Diabetologia 33: 465-469

20. Bottazzo GF, Gleichman H (1986) Immunology and Diabetes Workshops: Report of the First International Workshop on the Standardisation of Cytoplasmic Islet Cell Antibodies. Diabetologia 29: $125-126$

21. Boitard C, Bonifacio E, Bottazzo GF, Gleichmann H, Molenaar J (1988) Report on the Third International Workshop (Stage 3) on the Standardisation of Cytoplasmic Islet Cell Antibodies. Diabetologia 31: 451-452

22. Lévy-Marchal C, Bridel MP, Sodoyez-Goffaux F, Koch M, Sodoyez JC, Czernichow P (1991) Superiority of radiobinding assay over ELISA for detection of insulin auto-antibodies in newly-diagnosed Type 1 diabetic children. Diabetes Care 14: 61-63

23. Doniach D, Bottazzo GF, Russel RCC (1979) Goitrous autoimmune thyroiditis (Hashimoto's disease). Clin Endocrinol Metab 8: $63-80$

24. Ju LY, Gu XF, Krishnamoorthy R, Charron D (1991) Application of silver training to the rapid typing of the polymorphism of HLA-DQ alleles by enzymatic amplification and allele specific restriction fragment length polymorphism. Electrophoresis 12: 270-273

25. Gorsuch AN, Spencer KM, Lister J, Mac Nally JM, Dean BM, Bottazzo GF (1981) Evidence of a long prediabetic period in type 1 diabetes mellitus. Lancet II: 1363-1365

26. Lévy-Marchal C, Papoz L, de Beaufort C et al. (1992) Clinical and laboratory features of Type 1 diabetic children at the time of diagnosis. Diab Med 9: 279-284

27. Bonifacio E, Boitard C, Gleichmann H et al. (1990) Assessment of precision, concordance, specificity, and sensitivity of islet cell antibody measurement in 41 assays. Diabetologia 33: 731-736
28. Landin-Olsson M(1990) Precision of the islet-cell antibody assay depends on the pancreas. J Clin Lab Anal 4: 289-294

29. Riley WJ, MacLaren N (1984) Islet cell antibodies are seldom transient. Lancet II: 1351-1352

30. Bruining GJ, Molenaar J, Tuk CW, Lindeman J, Bruining HJ, Marner B (1984) Clinical time course and characteristics of islet cell antibodies in childhood diabetes. Diabetologia 26: 24-29

31. Chase HP, Voss MA, Butler-Simon N, Hoops S, O'Brien D, Dobersen MJ (1987) Diagnosis of pre-Type 1 diabetes. J Pediatr 11: $807-812$

32. Hehmke K, Otten A, Willems W (1980) Islet-cell antibodies in children with mumps infection (Letter). Lancet II: 211

33. Gorsuch AN, Dean BM, Bottazzo GF, Lister J, Cudworth AG (1980) Evidence that Type 1 diabetes and thyrogastric autoimmunity have different genetic determinants. $\mathrm{Br}$ Med J 280: 145-147

34. Degnbol B, Green A (1978) Diabetes mellitus among first and second degree relatives of early onset diabetics. Ann Hum Gen (London) 42: 25-47

35. Vexiau P, Helmy-Khalil S, Mamoun F et al. (1986) Etude de 4 variétés d'anticorps anti-îlots de Langerhans chez 74 diabétiques insulino-dépendants et leurs familles en fonction du génotype HLA. (Fren.) Presse Méd 15: 383-386

36. Sheehy MJ, Scharf SJ, Rowe JR et al. (1989) A diabetes susceptible haplotype is best defined by a combination of HLA-DR and DQ alleles. J Clin Invest 83: 830-835

37. Todd JA, Bell JI, MacDevitt HO (1987) HLA-DQ $\beta$ gene contributes to susceptibility and resistance to insulin-dependent diabetes mellitus. Risk for diabetes among relatives of IDDM patients. Nature 329: 599-604

38. Lipton RB, Laporte RE, Dorman JS, Riley WJ, Trucco M, Becker DJ (1991) A combination of HLA-DQ $\beta$ non-Asp 57 homozygosity and positive islet cell antibody assay predicts insulindependent diabetes in relatives of children with IDDM. Diabetes 40 [Suppl 1]: 151A

39. Bœhm BO, Manfras B, Seißler J et al. (1991) Epidemiology and immunogenetic background of islet-cell antibody-positive nondiabetic schoolchildren. Diabetes 40: 1435-1439

40. Millward BA, Alviggi L, Hoskins PJ et al. (1986) Immune changes associated with insulin-dependent diabetes may remit without causing the disease: a study in identical twins. Br J Med 292: 793-796

Received: 8 November 1991

and in revised form: 6 February 1992

Dr. C. Lévy-Marchal

Service de Diabétologie,

Hôpital Robert Debré

48, Boulevard Sérurier

F-75019 Paris

France 